\title{
Milk Synthetic Response of the Bovine Mammary Gland to an Increase in the Local Concentration of Amino Acids and Acetate
}

\author{
N. G. Purdie, ${ }^{\dagger} \dagger^{1}$ D. R. Trout, $\neq$ D. P. Poppi, ${ }^{*}$ and J. P. Cant $†$ \\ *Schools of Animal Studies and Veterinary Science, University of Queensland, St. Lucia 4072, Brisbane, Australia \\ †Department of Animal and Poultry Science, and \\ ‡Department of Clinical Studies, University of Guelph, Ontario, N1G 2W1, Canada
}

\section{ABSTRACT}

Rates of secretion of components into milk are a function of precursor concentrations and parameters that describe expression of the milk synthetic enzymes and their sensitivity to precursor concentrations. To establish the enzymatic sensitivities of milk fat yield and mammary acetate utilization to circulating acetate concentration, lactating cows were infused for $10 \mathrm{~h}$ with 0 or $40 \mathrm{~g}$ of acetate/h in an external iliac artery supplying one udder half. In addition, to investigate the possibility that energy supply influences the milk protein response to an elevated amino acid (AA) concentration, 2 different AA profiles were infused with and without acetate. Six cows, fed a total mixed ration of $21 \%$ crude protein ad libitum, were infused with $\mathrm{AA}$ at $0 \mathrm{~g} / \mathrm{h}, 30 \mathrm{~g} / \mathrm{h}$ in the profile of rumen microbes, or $30 \mathrm{~g} / \mathrm{h}$ in the profile of milk proteins, in a $3 \times 2$ factorial arrangement with the 2 acetate treatments of 0 and $40 \mathrm{~g} / \mathrm{h}$, all in a $6 \times 6$ Latin square. Amino acid infusion caused a $60 \%$ increase, on average, in plasma concentration of AA entering the infused udder half. From the microbial AA profile, $49 \%$ of infused AA were taken up by the udder half, $42 \%$ of which occurred during the first pass. From the milk AA profile, $44 \%$ of infused AA were taken up by the udder half, $50 \%$ of which occurred during the first pass. There was an $8 \%$ increase in yield of milk protein with AA infusion, representing 7\% capture, but no effect of the infused profile. Acetate infusion caused a decrease in the yields of milk protein and lactose when AA were infused, but not when AA were absent. Milk fat yields were not affected, although acetate concentrations in plasma entering the infused udder half increased by $123 \%$ and mammary uptakes increased by $128 \%$. Mammary uptakes of long-chain fatty acids and $\beta$-hydroxybutyrate were not affected by acetate infusion, whereas glucose uptakes tended to increase. It was suggested that excess acetate may have been sequestered in adi-

Received June 28, 2007.

Accepted September 17, 2007.

${ }^{1}$ Corresponding author: npurdie@uoguelph.ca pose tissue in the udder. Yields of both protein and fat in milk showed a low sensitivity to the concentration of their precursors in circulation. It was concluded that the $\mathrm{Km}$ in Michaelis-Menten-type equations describing milk synthesis should be assigned a low value, and that the Vmax is regulated to bring about changes in milk yield and composition.

Key words: amino acid, acetate, arterial infusion, milk composition

\section{INTRODUCTION}

Milk is synthesized in the mammary glands from precursors taken out of blood. The process of milk synthesis is biochemical and its kinetics can be described by Michaelis-Menten-type equations that consider enzyme activities and amounts in parameters such as $\mathrm{Km}$ and Vmax to quantify the relationship between concentrations of milk precursors and the rate of chemical reactions that use them, including synthesis and secretion of milk components (Baldwin, 1995). Nutritional effects on rates of milk component secretion such as from increased protein supply forage:concentrate ratio, and so on arise through an influence on the parameters or the substrate concentrations, or both, of the milk synthetic equations. To isolate the effect of the milk precursor concentration in nutritional responses, we have used a short-term infusion protocol in lactating cows, in which the arterial concentration of the precursor of interest is elevated in one udder half for $10 \mathrm{~h}$ by close arterial infusion (Cant et al., 2001, 2002). If the nutritional response involves a change in the level of expression of certain enzymes, then $10 \mathrm{~h}$ is too short a time for the parameters of milk synthesis to change significantly. Mammary utilization of milk precursors and composition of milk secreted during the 10-h interval can then be taken to represent primarily an effect of precursor concentration alone.

When arterial AA concentrations were increased 2to 3 -fold for $10 \mathrm{~h}$ in cows fed a diet of $16 \% \mathrm{CP}$ and 1.7 Mcal of $\mathrm{NE}_{\mathrm{L}} / \mathrm{kg}$, milk protein yield only increased $13 \%$ (Cant et al., 2001). Similarly, milk lactose yield was 
not affected by a 1.8-fold elevation of plasma glucose concentration for $10 \mathrm{~h}$ (Cant et al., 2002). These and similar observations of small responses in milk component yields to large changes in precursor concentrations in vivo led to the conclusion that, in general, milk component secretion is insensitive to precursor concentrations (Cant et al., 2003), which means that the $\mathrm{Km}$ for utilization of the precursor must be substantially lower than the normal physiological concentration of the precursor. This conclusion lies in contrast to estimates of $\mathrm{Km}$ that have been obtained from fitting the concentration dependencies of milk fat and lactose synthesis in vitro. In culture, mammary cells exhibit $\mathrm{Km}$ values for biosynthetic use of acetate and glucose very similar to the physiological concentrations of the 2 precursors (Forsberg et al., 1984, 1985). The whole-cow simulation model of Baldwin (1995) assigns a $\mathrm{Km}$ of $1.8 \mathrm{mM}$ to the synthesis of milk fat from plasma acetate and a $\mathrm{Km}$ of $3.0 \mathrm{~m} M$ to the synthesis of lactose from plasma glucose. These $\mathrm{Km}$ values are equal to the reference concentrations of acetate and glucose, respectively, and would yield predictions of relatively large increases in fat and lactose yields in response to doubling of precursor concentrations.

The short-term effects of acetate concentration on milk fat synthesis in vivo have not been extensively studied. Over several days, $40 \mathrm{~g}$ of acetate/h infused into the rumen of cows stimulated yields of protein, fat, lactose, and total milk by approximately $12 \%$ (Rook and Balch, 1961). Compared with an isoenergetic infusion of intraruminal propionate, intraruminal acetate at 6 $\mathrm{g} / \mathrm{h}$ for $10 \mathrm{~d}$ into goats increased the yield of milk fat by $36 \%$ with no effect on yield of protein or milk volume (Lough et al., 1983). However, in the short-term, Linzell (1967) reported that intravenous acetate infusion for 3 $\mathrm{h}$ into a fasted goat to restore the prefasting concentration of acetate did not affect yield of milk or fat. To establish the sensitivities of milk fat yield and mammary acetate utilization to circulating acetate concentration, we infused lactating cows with sodium acetate or saline in an external iliac artery feeding one udder half.

Synthesis of milk proteins in the mammary glands is an energy-demanding process, and the possibility exists that a low sensitivity to AA supply may be the result of an inadequate supply of metabolic energy. A second objective of our work was to reexamine shortterm responses to elevated AA concentrations when acetate was also given to provide a supplemental source of energy. Third, given that the profile of AA available in circulation determines its quality for protein synthesis, we compared responses to 2 different profiles of infused AA, one based on the rumen microbial protein profile and one based on the milk protein profile.
Table 1. Ingredient and chemical composition of the TMR fed to all cows

\begin{tabular}{lc}
\hline Item & $\%$ \\
\hline Ingredient composition (\% as-fed) & \\
Alfalfa haylage & 60.0 \\
Corn & 15.0 \\
Wheat shorts & 15.7 \\
Barley & 14.3 \\
Soybean meal & 5.2 \\
Corn gluten meal & 2.2 \\
Soyplus & 2.2 \\
Molasses & 1.5 \\
Blood meal & 0.7 \\
Limestone & 1.0 \\
Tallow & 0.4 \\
Mineral mix & 1.7 \\
Chemical composition & \\
DM (\% as-fed) & 74.7 \\
CP (\% of DM) & 21.2 \\
Buffer solubility (\% of CP) & 37.9 \\
NDF insolubility (\% of CP) & 9.7 \\
ADF insolubility (\% of CP) & 5.8 \\
NDF (\% of DM) & 29.1 \\
ADF (\% of DM) & 20.5 \\
Cellulose $(\%$ of DM) & 17.2 \\
Lignin (\% of DM) & 3.28 \\
Fat (\% of DM) & 2.7 \\
Ash (\% of DM) & 8.2 \\
Calculated NE $(\mathrm{Mcal} / \mathrm{kg}$ of DM) & 1.67 \\
\hline
\end{tabular}

\section{MATERIALS AND METHODS}

\section{Animals, Treatments, and Sampling}

All animal procedures were approved by the Animal Care Committee of the University of Guelph. Six nonpregnant, lactating Holstein cows (198 \pm 23 DIM) were fitted with polyethylene catheters that terminated in left and right external iliac arteries, and polyurethane catheters in left and right subcutaneous abdominal veins draining the udder (Cant et al., 2001). The position of the arterial catheters was confirmed by unilateral appearance of Evans Blue dye in the venous catheter following rapid arterial injection.

After catheterization surgery, cows were fed a TMR (Table 1) of alfalfa haylage and a concentrate mixed in a 60:40 proportion, respectively, by weight. Hand-mixed TMR was fed ad libitum at each milking with refusals removed and weighed at $0730 \mathrm{~h}$ to calculate DMI. A grab sample of the TMR was acquired a number of times during the experiment for analysis. Each consignment of concentrate and each load of haylage were sampled for analysis.

Cows were milked in the same order at 0800 and $1800 \mathrm{~h}$. A dual-bucket system was used with the milking claw divided into 2 sections so that milk from right and left udder halves was collected separately. Milk was weighed and a sample from each test bucket was collected for analysis. 
Table 2. Composition of AA infusates (g/3 L)

\begin{tabular}{lrr}
\hline Amino acid & $\begin{array}{c}\text { Microbial AA } \\
\text { profile }\end{array}$ & $\begin{array}{c}\text { Milk AA } \\
\text { profile }\end{array}$ \\
\hline Glu & 42.00 & 64.35 \\
Asp & 39.12 & 23.76 \\
Ile & 18.28 & 17.49 \\
Leu & 25.98 & 29.70 \\
Met & 8.35 & 7.92 \\
Phe & 32.07 & 30.36 \\
Thr & 18.60 & 15.84 \\
Trp & 5.12 & 4.95 \\
Val & 19.87 & 20.13 \\
Ala & 24.06 & 10.23 \\
Cys & 3.20 & 2.97 \\
Gly & 18.60 & 5.94 \\
Pro & 11.86 & 32.67 \\
Ser & 14.75 & 18.15 \\
Arg·HCl & 16.36 & 10.89 \\
His $\cdot$ HCl & 6.43 & 8.58 \\
Lys $\cdot$ HCl & 25.33 & 26.07 \\
\hline
\end{tabular}

The experiment was designed as a $3 \times 2$ factorial within a $6 \times 6$ Latin square, with 3 AA treatments: 0 $\mathrm{g} / \mathrm{h}, 30 \mathrm{~g} / \mathrm{h}$ in the profile of rumen microbes (Clark et al., 1992), and $30 \mathrm{~g} / \mathrm{h}$ in the profile of milk proteins (Hambraeus, 1982), and 2 acetate treatments: 0 and $40 \mathrm{~g} / \mathrm{h}$. Due to time constraints imposed by catheter patency, only 2 cows were subjected to the experiment at any one time. Thus, the $6 \times 6$ Latin square was accomplished in 3 consecutive, incomplete Latin squares. Infusion and sampling protocols were as previously used (Cant et al., 2001). Each period consisted of $10 \mathrm{~h}$ of continuous arterial infusion daily, followed by $14 \mathrm{~h}$ of rest.

Solutions were prepared the night before infusion in 3 -L batches. They were: $9 \mathrm{~g} / \mathrm{L}$ of saline, $110 \mathrm{~g} / \mathrm{L}$ of AA in the microbial profile (Table 2 ), $110 \mathrm{~g} / \mathrm{L}$ of AA in the milk profile (Table 2), $200 \mathrm{~g} / \mathrm{L}$ of sodium acetate, 200 $\mathrm{g} / \mathrm{L}$ of sodium acetate $+110 \mathrm{~g} / \mathrm{L}$ of microbial AA, and $200 \mathrm{~g} / \mathrm{L}$ of sodium acetate $+110 \mathrm{~g} / \mathrm{L}$ of milk AA. The Gln, Asn, and Tyr of the 2 AA profiles were replaced with molar equivalents of Glu, Asp, and Phe, respectively. Individual AA, purchased from USBiochemical (Cleveland, $\mathrm{OH}$ ) and Sigma Chemical Co. (Oakville, Ontario, Canada), were added to 2.5 L of Milli Q Ultrapure water [Millipore (Canada) Ltd., Mississauga, Ontario, Canada] containing $30 \mathrm{~g}$ of $\mathrm{NaOH}$ in the order listed in Table 2; each was dissolved before adding the next. All infusates were adjusted to $\mathrm{pH} 7.4$ by adding either $\mathrm{HCl}$ or $\mathrm{NaOH}$, subjected to a density determination by weighing $1-\mathrm{mL}$ aliquots 5 times, filtered through a $0.22-\mu \mathrm{m}$ cellulose acetate filter, and stored in $4-\mathrm{L}$ autoclaved, polypropylene bottles. The bottles were sealed and refrigerated overnight and were warmed before infusion.

Infusion into one arterial catheter began immediately after the $0800 \mathrm{~h}$ milking and continued until the 1800 $\mathrm{h}$ milking was complete. At $1500 \mathrm{~h}, 50 \mathrm{~mL}$ of $33 \%$ paraaminohippuric acid (PAH), as a marker to measure plasma flow rate, was injected through a $0.22-\mu \mathrm{m}$ syringe filter into the infusate bottle and mixed. At 1540, 1640 , and $1740 \mathrm{~h}$ (approximately 8, 9, and $10 \mathrm{~h}$ into the infusion), blood samples were collected simultaneously from the arterial catheter contralateral to infusion and the ipsilateral venous catheter. A syringe pump was used to withdraw blood continuously over $10 \mathrm{~min}$ into sodium EDTA Vacutainers (Becton Dickinson, Franklin Lakes, NJ) on ice. Infusate weight was recorded at the precise beginning and end of the sampling interval. Blood was centrifuged for collection of plasma, which was frozen at $-20^{\circ} \mathrm{C}$ until analyzed. Each infusate was sampled for chemical analysis.

\section{Analytical Procedures}

Milk samples were analyzed by infrared spectroscopy for protein, fat, and lactose content (AOAC, 1996). The 3 plasma samples from each blood vessel were analyzed individually for PAH and pooled for analysis of glucose, triacylglycerol, NEFA, and acetate concentrations by spectrophotometry, and for AA by reversed-phase HPLC, as previously described (Cant et al., 2001). Infusates were also analyzed for $\mathrm{PAH}$ and acetate accordingly.

Iliac plasma flow (IPF) at each of the 3 sampling timepoints was calculated from $\mathrm{PAH}$ analyses as

$\operatorname{IPF}(\mathrm{L} / \mathrm{h})=$

volume infused over $10 \mathrm{~min}(\mathrm{~L}) \times$ infusate $[\mathrm{PAH}](\mathrm{mg} / \mathrm{L}) \times 60 \mathrm{~min} / \mathrm{h}$ $10 \mathrm{~min} \times\{$ venous $[\mathrm{PAH}](\mathrm{mg} / \mathrm{L})-$ contralateral arterial $[\mathrm{PAH}](\mathrm{mg} / \mathrm{L})\}$.

Mammary extraction of a plasma metabolite, calculated as the quotient of its arteriovenous difference and arterial concentration, is a consequence of both transmembrane transport and plasma flow. As an alternative to calculating extraction, then, the product of the first-order rate constant for capillary uptake (k) and the total volume of perfused capillaries $\left(\mathbf{V o l}_{\text {cap }} \cdot \mathbf{N}_{\text {cap }}\right)$ was calculated as $\mathrm{k} \cdot \mathrm{Vol}_{\text {cap }} \cdot \mathrm{N}_{\text {cap }}=-\ln (1-$ extraction $) \times$ IPF, according to Cant and McBride (1995).

\section{Statistical Analyses}

Variance in each observation $\left(\mathrm{Y}_{\mathrm{ijklm}}\right)$ was analyzed by using the following model, with the GLM procedure of SAS Institute (2000):

$$
\begin{gathered}
\mathrm{Y}_{\mathrm{ijklm}}=\mu \ldots+\mathrm{sq}_{\mathrm{i}}+\operatorname{cow}(\mathrm{sq})_{\mathrm{j}(\mathrm{i})}+\mathrm{per}_{\mathrm{k}}+\mathrm{aa}_{\mathrm{l}}+\mathrm{ac}_{\mathrm{m}} \\
+\mathrm{aa}_{\mathrm{l}} \times \mathrm{ac}_{\mathrm{m}}+\varepsilon_{\mathrm{ijklm}}
\end{gathered}
$$


Table 3. Average yield and composition of milk from the infused udder half of 6 cows after $10 \mathrm{~h}$ of infusion into one external iliac artery of $0 \mathrm{~g} / \mathrm{h} \mathrm{AA}, 30 \mathrm{~g} / \mathrm{h}$ in the profile of rumen microbes (microb AA), or $30 \mathrm{~g} / \mathrm{h}$ in the profile of milk proteins (milk AA), with 0 (without) or 40 $\mathrm{g} / \mathrm{h}$ (with) acetate

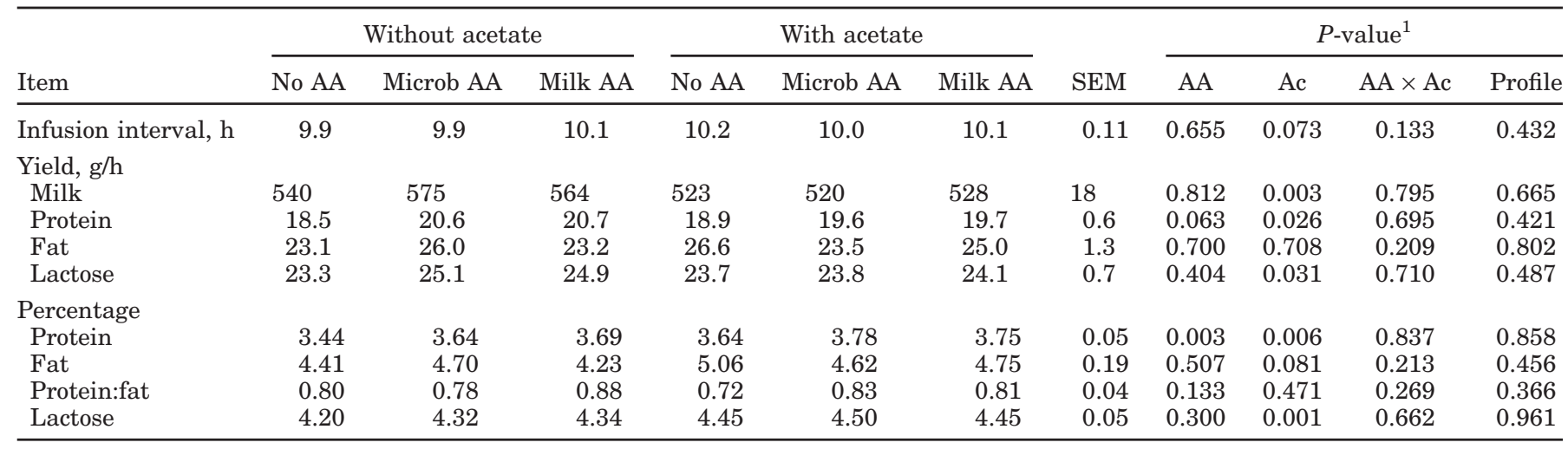

${ }^{1}$ Probabilities from ANOVA of no effect of infusion of AA, infusion of acetate (Ac), and their interaction (AA $\times$ Ac), and probability from orthogonal contrast of no effect of profile of AA infusate (profile).

where $\mu \ldots=$ mean, $\mathrm{sq}_{\mathrm{i}}=$ ith square effect $(1=1$ to 3$)$, $\operatorname{cow}_{\mathrm{j}(\mathrm{i})}=\mathrm{jth}$ cow effect within each ith square $(\mathrm{j}=1$ to $6), \operatorname{per}_{\mathrm{k}}=\mathrm{kth}$ period effect $(\mathrm{k}=1$ to 6$), \mathrm{aa}_{\mathrm{l}}=$ lth AA infusion effect $(1=1$ to 3$), \mathrm{ac}_{\mathrm{m}}=\mathrm{mth}$ acetate infusion effect ( $\mathrm{m}=1$ to 2 ), and $\varepsilon_{\mathrm{ijk} k \mathrm{~m}}=$ error.

Effect of the AA profile was evaluated with an orthogonal contrast between lth AA treatments 2 and 3. Significances of effects were declared at $P \leq 0.05$ and tendencies were declared at $0.05>P \leq 0.15$.

To test for carryover of treatment effects from one period to the next, the following ANOVA model was used:

$$
\mathrm{Y}_{\mathrm{ijkl}}=\mu \ldots+\mathrm{sq}_{\mathrm{i}}+\operatorname{cow}(\mathrm{sq})_{\mathrm{j}(\mathrm{i})}+\operatorname{per}_{\mathrm{k}}+\operatorname{prevtrt}_{\mathrm{l}}+\varepsilon_{\mathrm{ijkl}}
$$

where $\mu \ldots=$ true grand mean, $\mathrm{sq}_{\mathrm{i}}=$ ith square effect ( $1=1$ to 3$), \operatorname{cow}_{\mathrm{j}(\mathrm{i})}=$ jth cow effect within each ith square ( $\mathrm{j}=1$ to 6$),$ per $_{\mathrm{k}}=\mathrm{kth}$ period effect $(\mathrm{k}=1$ to 6$)$, prevtrt $_{\mathrm{l}}=$ lth previous treatment effect $(1=1$ to 6$)$, and $\varepsilon_{\mathrm{ijklm}}=$ error.

No carryover effects were detected for any of the observed variables.

\section{RESULTS}

Feed intake averaged $29.8 \mathrm{~kg} / \mathrm{d}(\mathrm{SEM}=1.4)$ over the experiment and was not affected by treatment. The infusion rate was maintained at $4.88 \mathrm{~mL} / \mathrm{min}(\mathrm{SEM}=$ $0.18)$ or $293 \mathrm{~mL} / \mathrm{h}(\mathrm{SEM}=11)$.

\section{Effects of AA Infusion}

The only effect of AA infusion on milk components from the infused udder half was a tendency for an $8 \%$ increase in protein yield (Table 3). Because milk yield remained unchanged, protein percentage was greater following AA infusion. The profile of the AA infusate made no difference in milk components.

Amino acid infusion caused arterial plasma glucose and insulin concentrations to increase (Table 4). There was a tendency for the $\mathrm{k} \cdot \mathrm{Vol}_{\text {cap }} \cdot \mathrm{N}_{\text {cap }}$ product for glucose to increase, which, in combination with the elevated arterial concentration, brought about an increased mammary uptake of glucose by an average of $79 \mathrm{mmol} /$ $\mathrm{h}$. The microbial profile resulted in a greater plasma glucose concentration than the milk profile but had no effect on mammary glucose balance. Effects of AA infusion on acetate balance were similar to those for glucose balance (Table 4). The systemic arterial concentration was elevated, tended to be more elevated by the microbial profile than by the milk profile, the $\mathrm{k} \cdot \mathrm{Vol}_{\text {cap }} \cdot \mathrm{N}_{\text {cap }}$ product increased, and so, mammary uptake of acetate increased by an average of $101 \mathrm{mmol} / \mathrm{h}$. There was an interaction between main effects on BHBA uptake, in which AA infusion without acetate increased BHBA uptake and, when acetate was infused, decreased BHBA uptakes. Net utilization of long-chain fatty acids (LCFA) by the mammary glands was not affected, although arterial concentrations of triacylglycerol were decreased slightly by infusion of the microbial profile (Table 4).

Infusion of AA caused an increased concentration in the general circulation of Phe, Val, Ile, Leu, Pro, and Ala, and tended to increase Arg and Ser (Table 5). The milk AA profile generated a greater Pro concentration, and tended to have greater Val, Ile, and Arg concentrations compared with the microbial AA profile. The concentrations of infused AA in the artery entering the infused glands were elevated an average of $60 \%$. On the milk AA profile, close arterial plasma was greater in Leu, Pro, and Ser, lower in Asp, and tended to be 
Table 4. Average plasma flow and balance of plasma metabolites across the infused udder half of 6 cows during the last $3 \mathrm{~h}$ of a 10 -h infusion into one external iliac artery of $0 \mathrm{~g} / \mathrm{h} \mathrm{AA}, 30 \mathrm{~g} / \mathrm{h}$ in the profile of rumen microbes (microb AA), or $30 \mathrm{~g} / \mathrm{h}$ in the profile of milk proteins (milk AA), with 0 (without) or $40 \mathrm{~g} / \mathrm{h}$ (with) acetate

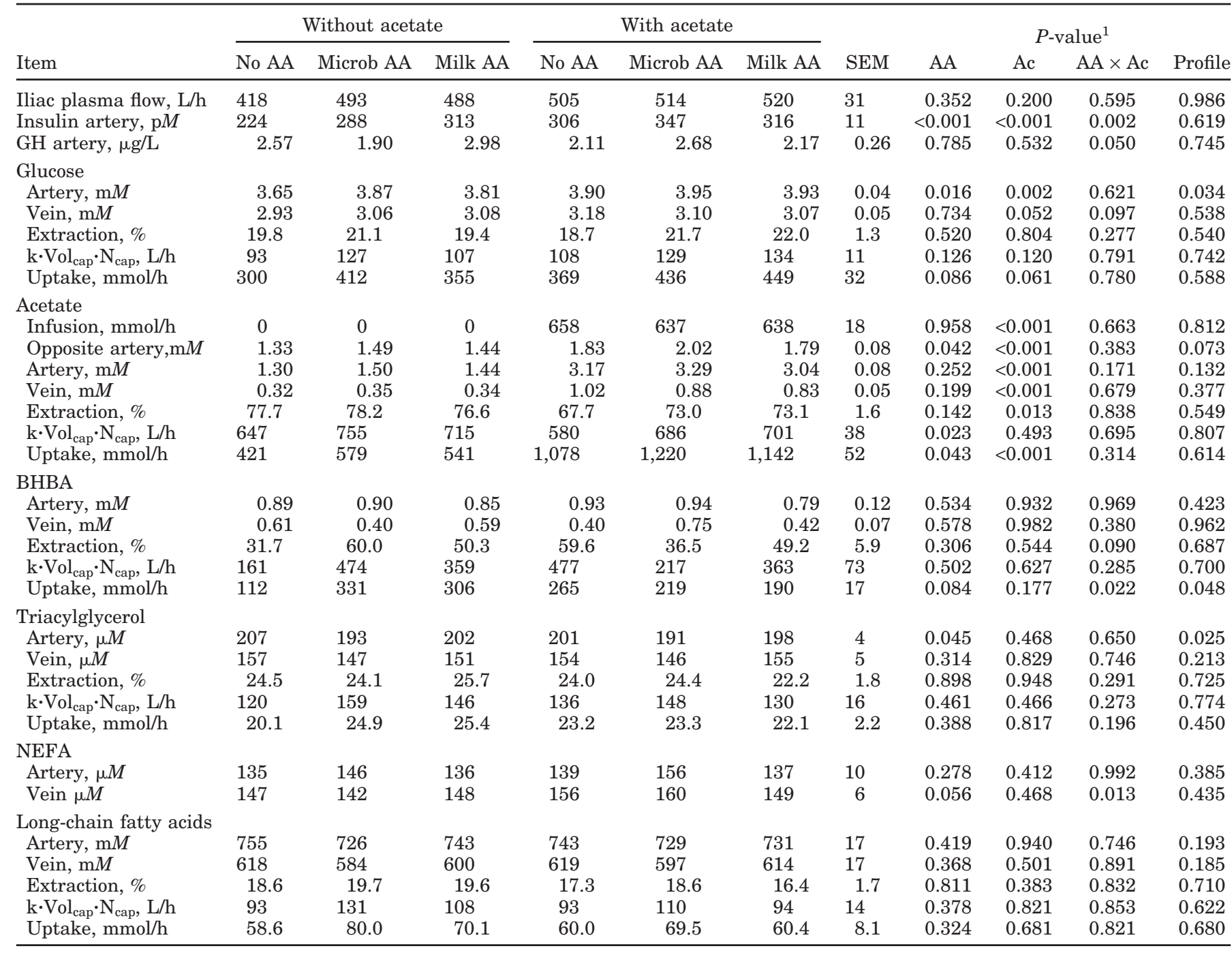

${ }^{1}$ Probabilities from ANOVA of no effect of infusion of amino acids (AA), infusion of acetate (Ac), and their interaction (AA $\times$ Ac), and probability from orthogonal contrast of no effect of profile of AA infusate (profile).

greater in Val and lower in Gly. There was an increased extraction of arterial Asp by the mammary glands during AA infusion, a decreased extraction of Ile, and a tendency toward a decreased extraction of Phe, Val, Leu, Ser, and Ala. Extraction of Ser was lower on the milk AA profile compared with the microbial AA profile and extractions of Phe and Val tended to be lower. Uptakes of Phe, Glu, and Asp were significantly increased more than 2-fold by AA infusion; uptakes of Leu, Arg, and Ser tended to be increased. On the milk AA profile, Asp uptake by the mammary glands was lower than on the microbial AA profile, and Phe and Ala uptakes tended to be lower.

\section{Effects of Acetate Infusion}

There was a significant effect of acetate on yield of milk protein and lactose, which was only manifest on the treatments with AA infusion (Table 3 ). Without AA, mean protein and lactose yields were approximately equal with or without acetate. With AA, protein and lactose yields were $5 \%$ lower with acetate than without. Thus, the effect of the acetate infusion was to prevent or attenuate the increase in lactose and protein yield brought about by the AA infusion. Milk fat yields were not affected by acetate infusion. Percentages of protein and lactose in milk were elevated and fat percentage tended to increase. 
Table 5. Average balance of selected plasma amino acids across the infused udder half of six cows during the last $3 \mathrm{~h}$ of a 10 -h infusion into one external iliac artery of $0 \mathrm{~g} / \mathrm{h} \mathrm{AA}, 30 \mathrm{~g} / \mathrm{h}$ in the profile of rumen microbes (microb AA), or $30 \mathrm{~g} / \mathrm{h}$ in the profile of milk proteins (milk AA), with 0 (without) or $40 \mathrm{~g} / \mathrm{h}$ (with) acetate

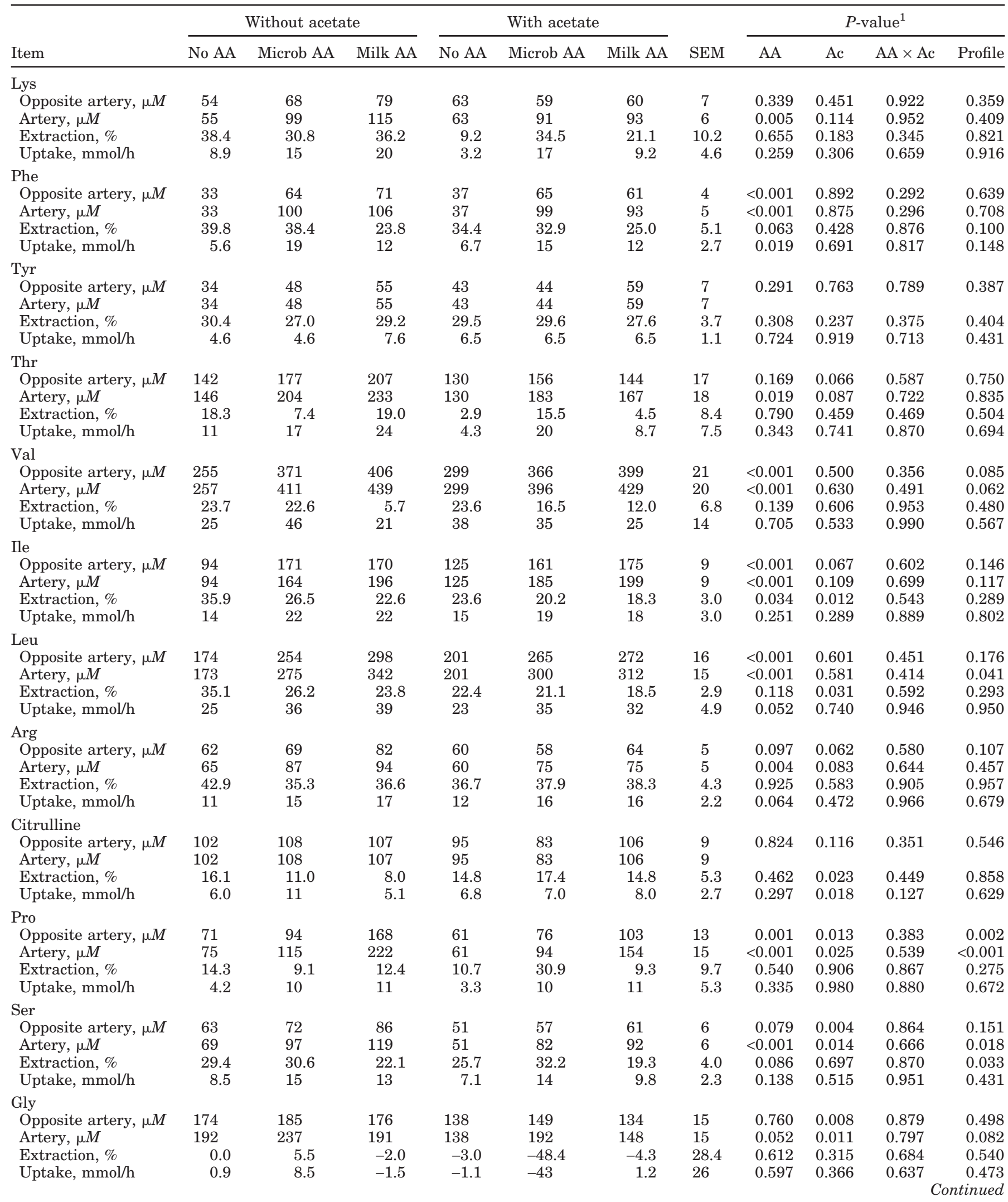


Table 5 Continued. Average balance of selected plasma amino acids across the infused udder half of six cows during the last $3 \mathrm{~h}$ of a 10 $\mathrm{h}$ infusion into one external iliac artery of $0 \mathrm{~g} / \mathrm{h} \mathrm{AA}, 30 \mathrm{~g} / \mathrm{h}$ in the profile of rumen microbes (microb AA), or $30 \mathrm{~g} / \mathrm{h}$ in the profile of milk proteins (milk AA), with 0 (without) or $40 \mathrm{~g} / \mathrm{h}$ (with) acetate

\begin{tabular}{|c|c|c|c|c|c|c|c|c|c|c|c|}
\hline Item & \multicolumn{3}{|c|}{ Without acetate } & \multicolumn{3}{|c|}{ With acetate } & SEM & \multicolumn{4}{|c|}{$P$-value $^{1}$} \\
\hline \multicolumn{12}{|l|}{ Ala } \\
\hline Artery, $\mu M$ & 237 & 319 & 284 & 199 & 290 & 264 & 14 & 0.001 & 0.207 & 0.931 & 0.536 \\
\hline Extraction, \% & 19.9 & 16.0 & 6.2 & 12.0 & 12.4 & 3.6 & 4.0 & 0.085 & 0.295 & 0.814 & 0.085 \\
\hline Uptake, $\mathrm{mmol} / \mathrm{h}$ & 21 & 27 & 8.1 & 12 & 17 & 6.9 & 6.1 & 0.257 & 0.387 & 0.829 & 0.110 \\
\hline Extraction, \% & 37.1 & 41.0 & 51.8 & 40.9 & 29.9 & 60.5 & 14.4 & 0.824 & 0.976 & 0.818 & 0.816 \\
\hline Uptake, mmol/h & 16 & 27 & 51 & 15 & 34 & 64 & 9 & 0.016 & 0.900 & 0.580 & 0.278 \\
\hline \multicolumn{12}{|l|}{ Asp } \\
\hline Opposite artery, $\mu M$ & 14 & 15 & 14 & 8 & 14 & 9 & 2 & 0.154 & 0.186 & 0.833 & 0.596 \\
\hline Artery, $\mu M$ & 15 & 68 & 48 & 8 & 65 & 41 & 3 & $<0.001$ & 0.384 & 0.397 & $<0.001$ \\
\hline Extraction, \% & 12.3 & 79.8 & 70.7 & 5.8 & 78.4 & 67.1 & 11.6 & $<0.001$ & 0.905 & 0.848 & 0.400 \\
\hline
\end{tabular}

${ }^{1}$ Probabilities from ANOVA of no effect of infusion of amino acids (AA), infusion of acetate (Ac), and their interaction (AA $\times$ Ac), and probability from orthogonal contrast of no effect of profile of AA infusate (profile).

Plasma acetate concentrations were elevated $33 \%$ in the general arterial circulation and $123 \%$ in the close arterial circulation of the infused udder half (Table 4). Extraction of arterial acetate by the infused udder half was decreased by the infusion but the $\mathrm{k} \cdot \mathrm{Vol}_{\text {cap }} \cdot \mathrm{N}_{\text {cap }}$ product was not actually affected, so the $123 \%$ increase in mammary acetate uptake was due entirely to the increase in arterial acetate concentration. Arterial glucose and insulin concentrations were elevated by acetate infusion (Table 4), the $\mathrm{k} \cdot \mathrm{Vol}_{\text {cap }} \cdot \mathrm{N}_{\text {cap }}$ tended to be increased and so mammary uptake of glucose increased $18 \%$. There was no change in BHBA, triacylglycerol, or LCFA supply or utilization by the mammary glands (Table 4).

During acetate infusion, there were decreased concentrations in the arterial circulation of Pro, Ser, and Gly and tendencies for decreases in Thr, Arg, citrulline (Cln), and Ala (Table 5). Isoleucine concentration tended to increase with acetate. Close arterial concentrations were similarly affected. Proline, Ser, and Gly decreased, Lys, Thr, Arg, and Cln tended to decrease, and Ile tended to increase. Extraction of the close arterial Ile and Leu decreased and extraction of Cln increased. The only AA uptake affected by acetate infusion was a $23 \%$ increase in Cln uptake.

\section{DISCUSSION}

\section{Sensitivity to AA Concentrations}

Amino acid concentrations were elevated by an average of $60 \%$ in the artery supplying one udder half, which is considerably less than the $280 \%$ elevation produced by close arterial infusion of $30 \mathrm{~g}$ of $\mathrm{AA} / \mathrm{h}$ previously reported (Cant et al., 2001). In the previous experiment, cows were fed a diet of $16 \% \mathrm{CP}$ compared with $21 \%$ this time, and so basal concentrations of most AA in arterial plasma were initially greater. Regardless, the small but detectable increase in milk protein yield, despite a $60 \%$ increase in circulating AA concentrations, confirms the low sensitivity of product formation to precursor concentration. In other words, formulation of the Michaelis-Menten equation(s) describing milk protein production should consider a Km for AA lower than the normal physiological concentration of AA. The strongest treatment effect was a $2.1 \mathrm{~g} / \mathrm{h}$ increase in milk protein yield in response to $30 \mathrm{~g} / \mathrm{h}$ of supplemental AA, accounting for approximately $7 \%$ of the infusate. In longer infusion experiments, in which a greater proportion of the added AA is recovered in milk protein (Hanigan et al., 1998), the parameters of the Michaelis-Menten equation, or what we have called the setpoint (Cant et al., 1999), must have changed.

Aside from the capture in milk protein, 2 other marginal efficiency measures can be calculated from the mammary arteriovenous difference data. One measure is the extraction of arterially infused AA on the first pass through the mammary glands, which was calculated as $\left(\mathrm{ex}_{\mathrm{i}} \mathrm{A}_{\mathrm{i}}-\mathrm{ex}_{0} \mathrm{~A}_{0}\right) /\left(\mathrm{A}_{\mathrm{i}}-\mathrm{A}_{0}\right)$, where $\mathrm{ex}_{\mathrm{i}}$ and $\mathrm{ex}_{0}$ are the arteriovenous extraction percentages on the infused and opposite sides, respectively, and $\mathrm{A}_{i}$ and $\mathrm{A}_{0}$ are the respective arterial concentrations. Because $\mathrm{ex}_{0}$ was not measured, it was estimated from the slope of the change in extraction percentages over the change in arterial AA concentrations between control and AA infusions 
Table 6. Marginal efficiencies of utilization of infused AA by the infused udder half of six cows during the last $3 \mathrm{~h}$ of a 10-h infusion into one external iliac artery of $30 \mathrm{~g} / \mathrm{h}$ AA in the profile of rumen microbes (microbial AA) or milk proteins (milk AA)

\begin{tabular}{|c|c|c|c|c|c|c|}
\hline \multirow[b]{2}{*}{ AA } & \multicolumn{3}{|c|}{ Microbial AA } & \multicolumn{3}{|c|}{ Milk AA } \\
\hline & $\begin{array}{c}\text { Infusion } \\
\text { rate, } \\
\mathrm{mmol} / \mathrm{h}\end{array}$ & $\begin{array}{l}\text { First-pass } \\
\text { extraction, } \\
\% \text { of infused }\end{array}$ & $\begin{array}{l}\text { Increase in } \\
\text { net uptake, } \\
\% \text { of infused }\end{array}$ & $\begin{array}{l}\text { Infusion } \\
\text { rate, } \\
\mathrm{mmol} / \mathrm{h}\end{array}$ & $\begin{array}{l}\text { First-pass } \\
\text { extraction } \\
\% \text { of infused }\end{array}$ & $\begin{array}{l}\text { Increase in } \\
\text { net uptake, } \\
\% \text { of infused }\end{array}$ \\
\hline Lys & 14.7 & 48 & 68 & 16.3 & 36 & 52 \\
\hline Phe & 16.5 & 34 & 66 & 16.8 & 11 & 35 \\
\hline Thr & 13.3 & 14 & 82 & 12.2 & 15 & 71 \\
\hline Val & 14.4 & 8 & 62 & 15.7 & -29 & -54 \\
\hline Ile & 11.8 & 7 & 51 & 12.2 & 2 & 45 \\
\hline Leu & 16.8 & 10 & 68 & 20.7 & 6 & 55 \\
\hline Arg & 8.0 & 26 & 50 & 5.7 & 30 & 87 \\
\hline Pro & 8.8 & 37 & 71 & 26.0 & 9 & 28 \\
\hline Ser & 11.9 & 40 & 56 & 15.8 & 10 & 23 \\
\hline Gly & 21.0 & -89 & -81 & 7.2 & -60 & -1 \\
\hline Ala & 22.9 & -9 & 24 & 10.5 & -45 & -86 \\
\hline Glu & 24.3 & 29 & 62 & 40.0 & 74 & 105 \\
\hline Asp & 25.0 & 98 & 98 & 16.3 & 90 & 83 \\
\hline Weighted average & & 21 & 49 & & 22 & 44 \\
\hline
\end{tabular}

as $\mathrm{ex}_{\mathrm{c}}+\left(\mathrm{A}_{\mathrm{o}}-\mathrm{A}_{\mathrm{c}}\right)\left(\mathrm{ex}_{\mathrm{i}}-\mathrm{ex}_{\mathrm{c}}\right) /\left(\mathrm{A}_{\mathrm{i}}-\mathrm{A}_{\mathrm{c}}\right)$, where $\mathrm{ex}_{\mathrm{c}}$ and $\mathrm{A}_{\mathrm{c}}$ are the extraction percentages and arterial concentrations during control infusions. First-pass extractions of infused AA ranged from -89 to $98 \%$ (Table 6) and for many AA tended to be lower than extraction of the basal arterial concentration. This decline in percentage extraction of AA as arterial concentrations increase has been noted previously (Hanigan et al., 1992; Tesseraud et al., 1992) and is likely a consequence of the bidirectional transport of AA across the mammary glands. Amino acids taken into mammary cells have a greater chance of returning to the circulation when the proportion incorporated into protein is decreasing (Bequette et al., 2001), as was occurring during AA infusion in this study. Net first-pass extraction of the entire infusate, on a molar basis, averaged $21 \%$ for the microbial AA profile and $22 \%$ for the milk AA profile.

Amino acids infused into the external iliac artery that bypass the udder half become available for the entire body to use, and a second marginal efficiency measure depends on the division of infused AA among all tissues of the body. This efficiency is the proportion of infused AA taken up on a net basis by the infused udder half, and it ranged from -86 to $105 \%$ for the individual AA (Table 6). From the microbial AA profile infusate, $49 \%$ of the AA were taken up by the udder half, $42 \%$ of which occurred during the first pass. From the milk AA profile infusate, $44 \%$ of infused AA were taken up by the udder half, $50 \%$ of which occurred during the first pass. These proportions are overestimates to the extent that external iliac blood is diverted through the femoral artery to the hind leg, which we have estimated to be, at most, $20 \%$. Thus, it appears that approximately $60 \%$ of the infused AA was used elsewhere in the body and, given only $7 \%$ capture in milk protein, the majority of AA taken up by the mammary glands were not secreted as milk protein. We conclude that, although milk protein production exhibits a low $\mathrm{Km}$ for AA, mammary AA utilization in other pathways (i.e., catabolism) exhibits a higher $\mathrm{Km}$.

In addition to changes in mammary AA utilization, AA infusion caused insulin concentrations to increase in arterial plasma and stimulated the mammary uptake of the energy metabolites glucose and acetate. Insulin stimulates milk protein secretion when administered continuously over several days (Griinari et al., 1997), so the possibility exists that the small increase in milk protein yield observed over $10 \mathrm{~h}$ was due to this hormonal effect, and not to the AA per se. However, short-term infusions of insulin have not resulted in any detectable changes in mammary AA utilization (Laarveld et al., 1981; Tesseraud et al., 1992). Nor does insulin appear to influence glucose or acetate utilization by mammary tissue in the short term (Laarveld et al., 1985). Insulin concentration was most likely increased in response to elevated glucose concentrations, as well as the increase in AA concentration, because both are potent secretagogues of the hormone. The glucose and acetate concentrations likely increased as products of disposal of the $60 \%$ of the infused AA not used by mammary tissue. The approximately $20 \%$ increase in $\mathrm{k} \cdot \mathrm{Vol}$ cap $\mathrm{N}_{\text {cap }}$ products for glucose and acetate clearance by the mammary glands (Table 4) remains unexplained.

Few differences between the microbial and milk AA profiles were observed. The milk AA profile infused was substantially greater in Glu and Pro content and lower in Asp, Ala, Gly, and Arg (Tables 2 and 6). The difference between infusates in Pro content resulted in a 
greater Pro concentration in the general circulation of cows infused with the milk AA profile but none of the other differences were manifest (Table 5). In the close arterial plasma, the Pro, Asp, and Gly differences between infusates were retained. These AA are not generally considered to be important to milk synthesis, although the excessive uptake of Arg by the mammary glands for synthesis of the Pro and Glu of milk protein has prompted some investigation of Pro responses. The main effect of postruminal Pro supplementation (80 $\mathrm{g} / \mathrm{d})$ of cows appears to be a disproportionately large increase in milk fat yield (Bruckental et al., 1991), which has been shown to be a symptom of an AA imbalance rather than a corrected deficiency (Weekes et al., 2006). Arteriovenous differences of Arg were reduced during Pro infusion (Bruckental et al., 1991) and a similar sparing of the conversion of Arg to Pro in the mammary glands and elsewhere in the body may have occurred in this experiment such that Arg concentrations rose in both the general and the close arterial plasma with the milk AA profile compared with the microbial AA profile (Table 5), despite being infused at a slower rate. The branched-chain AA also tended to be greater in both infused and noninfused arteries with the milk AA profile compared with the microbial AA profile. This effect might be indicative of differences in hepatic AA utilization that consume little Val, Ile, and Leu. None of the differences in AA concentrations between infusate profiles had an effect on yield or composition of milk.

\section{Sensitivity to Acetate Concentration}

First-pass extraction by the infused udder half of the $645 \mathrm{mmol} / \mathrm{h}$ acetate infused into one external iliac artery was calculated from the difference between extraction percentages on the treatments with and without acetate, as for the AA above, to be $65 \%$. The proportion of infused acetate that was taken up by the infused udder half, on a net basis, was $98 \%$. Again, both these values are overestimates because of a fraction of blood in the external iliac artery that does not flow to the mammary glands. Nevertheless, it is apparent that a very high proportion of the acetate infusion was used by the mammary glands. In addition, because there was no change with acetate infusion in the $\mathrm{k} \cdot \mathrm{Vol}_{\text {cap }} \cdot \mathrm{N}_{\text {cap }}$ product representing clearance of plasma acetate by the mammary glands, the uptake of acetate can be said to be a direct consequence of the arterial acetate concentration. More specifically, the hypothesis holds that acetate uptake follows first-order, mass-action kinetics. This hypothesis was also upheld by close arterial glucose infusions during which IPF decreased by $16 \%$ but the first-order rate constant for mammary acetate up- take did not change, so acetate uptake decreased (Cant et al., 2002).

When glucose infusion caused acetate uptake by the mammary glands to decrease, there was no concomitant decrease in milk fat yield (Cant et al., 2002). Likewise, the increase in acetate uptake induced by acetate infusion in this experiment caused no significant change in milk fat yield. Linzell (1967) also reported no change in milk or fat yield of a fasted goat infused for $3 \mathrm{~h}$ with acetate. In a preliminary experiment, acetate infusion at graded levels up to $36 \mathrm{~g} / \mathrm{h}$ into the external iliac artery of 4 cows for $10 \mathrm{~h}$ did not affect milk fat yields or percentages (Maas et al., 1995). The evidence is strong that fat yield is not sensitive to acetate concentrations or uptake by the mammary glands. In this experiment we add evidence to indicate that net BHBA and LCFA disappearance across the mammary glands is also not affected by a high acetate concentration. Thus, the additional acetate does not appear to induce a change in the use of other fat precursors.

The implication of no effect of acetate concentration, for mechanistic modeling of milk synthesis using Michaelis-Menten-type equations, is that the $\mathrm{Km}$ value should be set much lower than the physiological concentration of plasma acetate. This conclusion conflicts with the $\mathrm{Km}$ of $1.2 \mathrm{~m} M$ estimated from conversions of $\left[1-{ }^{14} \mathrm{C}\right]$ acetate to fatty acids by mammary tissue incubated in vitro (Forsberg et al., 1984). However, Baldwin (1995) reported that the simulation model MOLLY, with a $\mathrm{Km}$ for acetate conversion to milk triacylglycerol of $1.8 \mathrm{~m} M$, predicted an approximately $40 \%$ increase in milk fat yield when blood acetate concentration was increased over the range we investigated, from 1.3 to $3.3 \mathrm{~m} M$. A $\mathrm{Km}$ one order of magnitude smaller (i.e., $0.18 \mathrm{mM}$ ) would yield an $8 \%$ increase in predicted milk fat yield. The Baldwin (1995) model was designed to describe longer-term responses to dietary perturbations, not within a day, as in this experiment. Longerterm infusions of acetate have indeed resulted in increased milk fat yields (Rook and Balch, 1961; Lough et al., 1983). Our suggestion is that the Vmax for milk fat synthesis from acetate must increase to bring about this response. The Vmax represents enzymatic capacity, which would be expected to increase over the course of a few days, and not within the 10-h timeframe of our experiment. The combination of an increase in Vmax for each increase in acetate concentration over the long term could generate an aggregate response curve that appears very similar to a saturating Michaelis-Mententype curve (Cant et al., 1999). Thus, the $\mathrm{Km}$ that is used for long-term simulations of mammary responses to circulating concentrations of milk precursors may express a different level of aggregation than the shortterm $\mathrm{Km}$ and the two should not be confused. 
If acetate uptake increased $123 \%$ but milk fat yield and BHBA and LCFA uptakes were not significantly affected, where did the additional acetate go? There is a time delay between uptake of acetate from the blood plasma and output in milk of the fat synthesized from it. Thus, some of the infused acetate may have been incorporated into milk fat that was secreted after our 10-h infusion period. Fat secreted during the 14-h milking interval after acetate infusions ceased was $13.6 \mathrm{~g}$ higher than after the other infusions ceased, which, if $40 \%$ by weight of the fat is synthesized from acetate, could account for only $151 \mathrm{mmol}$ of acetate uptake. Even in conjunction with $105 \mathrm{mmol}$ of acetate estimated to have been used in additional milk fat synthesis during the infusion period, most of the $6,392 \mathrm{mmol}$ of uptake remains unaccounted for. Aside from fat, the other main product of acetate utilization in mammary tissue is $\mathrm{CO}_{2}$ (Scott et al., 1976; Forsberg et al., 1984) in oxidative phosphorylation of adenosine nucleosides. But that would generate a lot of ATP whose use must be explained.

We have hypothesized in the past that the mammary glands exert control over the local rate of blood flow to match ATP production with its utilization (Cant and McBride, 1995). According to this hypothesis, it was predicted that IPF would decrease by $32 \%$ during close arterial infusion of $90 \mathrm{~g} / \mathrm{h}$ glucose, and it was actually observed to decrease by $16 \%$ (Cant et al., 2002). Simulations with the mammary model described by Cant et al. (2003), from concentrations of metabolites observed in this experiment, yield a predicted decrease in IPF to $322 \mathrm{~L} / \mathrm{h}$ to maintain ATP balance on the acetate infusion treatment, whereas it actually remained at $505 \mathrm{~L} / \mathrm{h}$ (Table 4). The data may be sufficient to disprove the hypothesis, although without a change in plasma flow there remains a problem of energy balance across the udder half to be resolved.

In addition to faster uptake of acetate that was not incorporated into a milk component, the high acetate concentration also stimulated uptake of glucose by $18 \%$ but lactose yields in milk were not affected. Presumably, then, the additional glucose was oxidized to yield ATP. Forsberg et al. (1985) observed a dramatic increase in rates of glucose oxidation by slices of mammary tissue incubated in vitro with increasing concentrations of acetate. Between the concentrations of 1.3 and $3.3 \mathrm{~m} M$ observed in our experiment, production of ${ }^{14} \mathrm{CO}_{2}$ from $\left[1-{ }^{14} \mathrm{C}\right]$ glucose increased approximately $25 \%$ and, from $\left[2-{ }^{14} \mathrm{C}\right]$ glucose, approximately $10 \%$ (Forsberg et al., 1985). The particular stimulation of glucose utilization in the pentose phosphate cycle implicates faster NADPH removal in fat synthesis from acetate yet, although we observed a similar increase in mammary glucose oxidation at the elevated acetate concentration, no change in milk fat synthesis was apparent. The energy balance problem and the stimulation of glucose oxidation can both be resolved if a good portion of the acetate that disappeared between artery and vein was taken up into adipose cells of the udder half and converted to triacylglycerol. An udder half may contain 1 to $3 \mathrm{~kg}$ of adipose tissue that responds in size to the nutritional status of the cow (Gibb et al., 1992) and, if it behaves similarly to subcutaneous depots, is more lipogenic in late lactation than early (McNamara and Hillers, 1986). In addition, when acetate is the primary substrate of lipogenesis in ruminant adipose tissue and glucose is used only for synthesis of the glycerol backbone of stored lipids (Vernon, 1980), the glucose we infused previously (Cant et al., 2002), in contrast to acetate here, would not have been taken up into mammary adipose and an IPF response was induced.

\section{CONCLUSIONS}

Yield of fat in milk was not affected by a $123 \%$ increase in arterial acetate concentration, despite a $128 \%$ increase in acetate uptake into mammary tissue. Yield of protein in milk was elevated $8 \%$ by a $60 \%$ increase in arterial AA concentrations and a $64 \%$ increase in mammary AA uptake. Acetate supply did not affect the response to AA infusion. The profile of circulating AA was not found to have a significant mass-action effect on yield of milk protein. These almost negligible responses highlight the low sensitivity of milk component output to a change in the concentration of its precursor arriving at the mammary glands. It would suggest that one should look to effects on mammary enzyme expression to explain longer-term, diet-mediated effects on milk component output. The implication for mechanistic modeling of milk synthesis using Michaelis-Mententype equations is that the precursor concentration has little effect, via a low $\mathrm{Km}$ value, and the Vmax is regulated to bring about changes in component yields. The absence of an effect of acetate infusion on IPF led to the suggestion that mammary adipose growth may have accounted for a large proportion of the infused acetate utilization.

\section{ACKNOWLEDGMENTS}

The authors wish to thank Mary Bargh, Scott Cieslar, Peter deVries, Sue Sinclair, Bev Livingston, Paul Luimes, Agnes Pillai, Fulong Qiao, Lori Sheehan, Melanie Sippel, Chanelle Toerien, Tammi Weekes, Tom Wright, and Changting Xiao for assistance with animal care, sampling, and laboratory analysis. Financial support for this work was provided by NSERC Canada, Agribrands Purina Canada, and the Ontario Ministry of 
Agriculture and Food. Norm Purdie was in receipt of a Dairy Research Development Corporation postgraduate award.

\section{REFERENCES}

AOAC. 1996. Official Methods of Analysis. 16th ed. Assoc. Offic. Anal. Chem., Arlington, VA.

Baldwin, R. L. 1995. Modeling ruminant digestion and metabolism. Chapman \& Hall, London, UK.

Bequette, B. J., C. E. Kyle, L. A. Crompton, V. Buchan, and M. D. Hanigan. 2001. Insulin regulates milk production and mammary gland and hind-leg amino acid fluxes and blood flow in lactating goats. J. Dairy Sci. 84:241-255.

Bruckental, I., I. Ascarelli, B. Yosif, and E. Alumot. 1991. Effect of duodenal proline infusion on milk production and composition in dairy cows. Anim. Prod. 53:299-303.

Cant, J. P., R. Berthiaume, H. Lapierre, P. H. Luimes, B. W. McBride, and D. Pacheco. 2003. Responses of the bovine mammary glands to absorptive supply of single amino acids. Can. J. Anim. Sci. 83:341-355.

Cant, J. P., and B. W. McBride. 1995. Mathematical analysis of the relationship between blood flow and uptake of nutrients in the mammary glands of a lactating cow. J. Dairy Res. 62:405-422.

Cant, J. P., F. Qiao, and C. A. Toerien. 1999. Regulation of mammary metabolism. Pages 203-219 in Protein metabolism and nutrition. Proceedings of the VIIIth International Symposium on Protein Metabolism and Nutrition. G. E. Lobley, A. White, and J. C. MacRae, ed. Wageningen Pers, Wageningen, the Netherlands.

Cant, J. P., D. R. Trout, F. Qiao, and B. W. McBride. 2001. Milk composition responses to unilateral arterial infusion of complete and histidine-lacking amino acid mixtures to the mammary glands of cows. J. Dairy Sci. 84:1192-1200.

Cant, J. P., D. R. Trout, F. Qiao, and N. G. Purdie. 2002. Milk synthetic response of the bovine mammary gland to an increase in the local concentration of arterial glucose. J. Dairy Sci. 85:494-503.

Clark, J. H., T. H. Klusmeyer, and M. R. Cameron. 1992. Microbial protein synthesis and flows of nitrogen fractions to the duodenum of dairy cows. J. Dairy Sci. 75:2304-2323.

Forsberg, N. E., R. L. Baldwin, and N. E. Smith. 1984. Roles of acetate and its interactions with glucose and lactate in cow mammary tissue. J. Dairy Sci. 67:2247-2254.

Forsberg, N. E., R. L. Baldwin, and N. E. Smith. 1985. Roles of glucose and its interactions with acetate in maintenance and biosynthesis in bovine mammary tissue. J. Dairy Sci. 68:2544-2549.

Gibb, M. J., W. E. Ivings, M. S. Dhanoa, and J. D. Sutton. 1992. Changes in body components of autumn-calving HolsteinFriesian cows over the first 29 weeks of lactation. Anim. Prod. 55:339-353.
Griinari, J. M., M. A. McGuire, D. A. Dwyer, D. E. Bauman, D. M. Barbano, and W. A. House. 1997. The role of insulin in the regulation of milk protein synthesis in dairy cows. J. Dairy Sci. 80:2361-2371.

Hambraeus, L. 1982. Nutritional aspects of milk proteins. Pages 289313 in Developments in Dairy Chemistry. 1. Proteins. P. F. Fox, ed. Applied Science Publishers, London, UK.

Hanigan, M. D., C. C. Calvert, E. J. DePeters, B. L. Reis, and R. L. Baldwin. 1992. Kinetics of amino acid extraction by lactating mammary glands in control and Sometribove-treated Holstein cows. J. Dairy Sci. 75:161-173.

Hanigan, M. D., J. P. Cant, D. C. Weakley, and J. L. Beckett. 1998. An evaluation of postabsorptive protein and amino acid metabolism in the lactating dairy cow. J. Dairy Sci. 81:3385-3401.

Laarveld, B., R. K. Chaplin, and R. P. Brockman. 1985. Effects of insulin on the metabolism of acetate, beta-hydroxybutyrate and triglycerides by the bovine mammary gland. Comp. Biochem. Physiol. 82B:265-267.

Laarveld, B., D. A. Christensen, and R. P. Brockman. 1981. The effect of insulin on net metabolism of glucose and amino acids by the bovine mammary gland. Endocrinology 108:2217-2221.

Linzell, J. L. 1967. The effect of infusions of glucose, acetate and amino acids on hourly milk yield in fed, fasted and insulin-treated goats. J. Physiol. 190:347-357.

Lough, D. S., E. C. Prigge, W. H. Hoover, and G. A. Varga. 1983. Utilization of ruminally infused acetate or propionate and abomasally infused casein by lactating goats. J. Dairy Sci. 66:756-762.

Maas, J. A., D. R. Trout, J. P. Cant, B. W. McBride, and D. P. Poppi. 1995. Method for close arterial infusion of the lactating mammary gland. Can. J. Anim. Sci. 75:345-349.

McNamara, J. P., and J. K. Hillers. 1986. Adaptations in lipid metabolism of bovine adipose tissue in lactogenesis and lactation. J. Lipid Res. 27:150-157.

Rook, J. A. F., and C. C. Balch. 1961. The effects of intraruminal infusions of acetic, propionic and butyric acids on the yield and composition of the milk of the cows. Br. J. Nutr. 15:361-369.

SAS Institute. 2000. SAS/STAT User's Guide: Version 8. SAS Institute, Inc., Cary, NC.

Scott, R. A., D. E. Bauman, and J. H. Clark. 1976. Cellular gluconeogenesis by lactating bovine mammary tissue. J. Dairy Sci. 59:50-56.

Tesseraud, S., J. Grizard, B. Makarski, E. Debras, G. Bayle, and C. Champredon. 1992. Effect of insulin in conjunction with glucose, amino acids and potassium on net metabolism of glucose and amino acids in the goat mammary gland. J. Dairy Res. 54:135149.

Vernon, R. G. 1980. Lipid metabolism in the adipose tissue of ruminant animals. Prog. Lipid Res. 19:23-106.

Weekes, T. L., P. H. Luimes, and J. P. Cant. 2006. Responses to amino acid imbalances and deficiencies in lactating dairy cows. J. Dairy Sci. 89:2177-2187. 